\title{
Jean Paulhan's Research in Oral Literature
}

\section{Lee Haring}

\section{(2) OpenEdition}

12 Journals

Electronic version

URL: https://journals.openedition.org/clo/1855

DOI: $10.4000 /$ clo. 1855

ISSN: 2266-1816

Publisher

INALCO

Printed version

Date of publication: 1 January 2014

ISBN: 978-2-85831-222-1

ISSN: 0396-891X

\section{Electronic reference}

Lee Haring, "Jean Paulhan's Research in Oral Literature", Cahiers de littérature orale [Online], 75-76

2014, Online since 29 April 2015, connection on 01 July 2021. URL: http://journals.openedition.org/ clo/1855 ; DOI: https://doi.org/10.4000/clo.1855

This text was automatically generated on 1 July 2021.

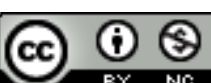

Cahiers de littérature orale est mis à disposition selon les termes de la Licence Creative Commons Attribution - Pas d'Utilisation Commerciale 4.0 International. 


\title{
Jean Paulhan's Research in Oral Literature
}

\author{
Lee Haring
}

1 The researcher in oral literature is the custodian of two discourses. One is "the system of poetic forms which make up the actual repertoire of a given community" (Jakobson and Bogatyrev, 1971, 93). The other is the system of concepts and methods making up the discourse of scholars. Oral literature, whether conceived as the object of study or the study itself, is one of those arts and sciences that Friedrich Schlegel $(1865,10)$ labeled as "mental exertions which have human life, and man himself, for their object". Using such a mental exertion as a window into a people and their values, the study of oral literature practices "the empirical field study of systems of signs in systems of use". This is the formulation of the American anthropologist, linguist, and folklorist Dell Hymes (1964, 9), who tirelessly sought to unify fields that had long kept themselves separate. The invention of "folklore" marks a moment of division between fields. The coiner of the term, William Thoms, "hoped to see the growth of a more systematic inquiry into manners and customs," says Regina Bendix. But the fate of this field, she goes on, was to submit to a division of labor, under diverse names like "Ethnology, Oral Literature, Folklife Studies, and traditions populaires" (Bendix, 2000, 3), and to lie apart from literary history. To regard the production and reproduction of literary studies as a totality is to reveal a continuum between written and oral literature, with Racine at one end and Griaule's Ogotemmêli (1948) at the other, separated only by the channel of communication (speaking or writing), united by their dependence on metaphor and metonymy. As Hymes conceived it, and as Dorothy Noyes phrases it (personal communication), "folklore" would be "a foundation for a unified philological project that would merge existing disciplines".

2 Foreseeing that unified project was Jean Paulhan (1884-1968), who drew no boundary between the oral and the written. How strange it is that Paulhan is known only as a littérateur. "If Paulhan's place," as Michael Syrotinski writes, "within a certain epoch of French intellectual history is assured" $(1998,151)$, his place in the history of oral literature studies is not. It is obscured. His critics, even when they scrutinize his 
commitment to secrecy (Trudel, 2004), stay within the confines of the Paris literary world which between the wars he admittedly came to dominate. Critics ignore the colonies and their cultural production; they carry worn-out assumptions about major and minor literature. Even the most sympathetic critic, Silvio Yeschua, says of the Malagasy folk poems Paulhan translated, "J'avouerai avoir longtemps cru que Paulhan les avait inventé..." (1982, 346-347). But those poems were quite real; translating, then performing them, then probing their aesthetic, fascinated Paulhan throughout his life. When he became that eminent literary figure, who studied words so skillfully without ever revealing himself, he never stopped thinking through his field experience in the colony. ${ }^{1}$

For a tense Jean-Paul Sartre, Paulhan played a crucial role at their first meeting in 1937.

[J]'ai monté deux étages et je me suis trouvé en face d'un grand type basané, avec une moustache d'un noir doux et qui va doucement passer au gris. Le type était vêtu de clair, un peu gros et m'a fait l'impression d'être brésilien. C'était Paulhan. Il m'a introduit dans son bureau; il parle d'une voix distinguée, avec un aigu féminin, ça caresse. (Beauvoir, 1960, 305).

4 The meeting was to end happily, with Paulhan's decision to recommend la Nausée for publication by the Nouvelle Revue Française, which he edited. He was already the central figure of France's literary world, the friend and professional associate of Paul Valéry, André Breton, Paul Éluard, Louis Aragon, Amédée Ozenfant, Robert Delaunay, and innumerable other titans. Less well known were his several novels (le guerrier appliqué, 1914; Lalie, 1915; Progrès en amour assez lents, 1917). At length he gained recognition for the key role he played as editor, publisher, and mentor. What remained almost secret were the principles he drew from his pioneering research in oral literature.

It was not a field he set out to specialize in. Though like every other literate Frenchman he certainly knew his Perrault, he had no interest in the rise of French folklore studies or the work of Henri Gaidoz, Paul Sébillot, or Emanuel Cosquin in previous generations; perhaps he knew Joseph Bédier's medieval studies or glanced at the journal Mélusine. His literary interests lay apart from these men's effort to legitimize le folklore and thereby make their contribution to the Third Republic. Paulhan's interests also lay apart from the effort of Émile Durkheim (1858-1917) to legitimize sociology. Field experience, he expected, would come to him outside France, perhaps in China.

6 In fact Paulhan's field experience took place in France's colony of Madagascar, where he lived for thirty-three months (1908-1910), much of that time with a bourgeois (hova) family in the capital, more briefly with a lower-class (andevo) family in the royal seat of Ambohimanga and an upper-class (andriana)family in the south. ${ }^{2}$ Perhaps it was only coincidence that Paulhan chose to live in a society experienced by his countrymen as so different, and so notably secretive. Once he had experienced the secrecy practiced in Madagascar, it would always hold an important place in his thinking and writing. Foreign observers like Louis Catat had already remarked on how sly and devious the Malagasy people seemed (Haring, 1992, 19). Today in retrospect, what seemed like deviousness is recognizable as deliberate concealment from the stranger. Malagasy narrators, for example, being interviewed or recorded by French civil servants or teachers and being asked to retell sacred narratives (tantara), would regularly withhold full performance. It was exactly because they knew tantara to be the truest narratives of all that they were to be kept back from the foreigner. Tsy misy melo-batana, fa izay melobava no meloka, said a proverb of the Merina, the large and powerful ethnie group whom Paulhan knew: No one is guilty in body, but the guilty-in-mouth is blameworthy. No 
ethnographer of Madagascar before Paulhan so deeply understood the importance of secrecy to colonized people; none before him discerned the skillful choices in language that Malagasy culture provided its members. His attempt to crack secrecy was to create a literary place for Madagascar in France and Europe.

7 Not that the Great Red Island was unknown. It had already drawn attention from the most advanced of social scientists. A few years before Paulhan set out, a formidable study of totem and taboo in Madagascar had been compiled from library sources by Arnold Van Gennep, eleven years Paulhan's senior, as a means of testing some sociological theories. Totem and taboo would envelop the totality of Madagascar, and the progress of ethnography would help the colonial project: "L'étude approfondie des sociétés demi-civilisées est de première nécessité pour quiconque veut faire œuvre de colonisation durable" (Van Gennep, 1904, 1). Van Gennep's library research later sent him out into the field, to produce ethnography that assured him a permanent place in French intellectual life, if only on the margins, as Nicole Belmont has shown (1974). Surveying Haute-Savoie from Bourg-la-Reine, he could turn his gaze away from the closed circle of Émile Durkheim. From that "somewhat doctrinaire group", as E. E. EvansPritchard called it, Van Gennep “ kept, or was kept, well away ” $(1960,17)$. Paulhan all the white was out in the field on his own, analyzing the ways Malagasy people used their language artistically.

8 Twelve years after France conquered the Great Red Island, there was an established place in the colony for young men who could teach. Thereby Paulhan saw lie could further his interest in the arts of language. Two months after arriving in the capital, he wrote an article on lying, which he hoped to get published in Paris. He could not yet have had much experience of lying from the Merina, though he surely heard from other colonials about their reputation for deviousness. His choice of lying as a topic indicates his double commitment, to language in itself and to the way the Malagasy used it. Far more interested in local people than were the French officers around him, Paulhan preferred fieldwork in the family among whom he lived to library research. To learn the family's language, he turned away from the standard Malagasy-French dictionary by Father Abinal (1963), as well as its predecessors, the dictionary and grammars produced by the British missionary Richardson (1885). Later, when he met Fr. Victorin Malzac, who completed Abinal's dictionary after the latter's death, Paulhan found him a linguist with preferences quite opposite to his own, a missionary interested in the Merina language but not in its people. "Il n'a aucune idée sur les Malgaches," Paulhan wrote.

Je lui dis : "Qu'est-ce que vous pensez du caractère des Malgaches?

- le caractère? Oh, c'est comme les Français, je pense. Ils n'en ont pas." (1982, 49).

9 Paulhan already knew them better, through language. What appealed to him was transcribing and translating proverbs from the family's dictation. After his time this activity would be named sociolinguistic fieldwork.

If Paulhan ignored much earlier proverb scholarship, it had a imposing history in France, for example the two books by P.-M. Quitard, which rank high in French folkloristics. One was a very large etymological, historical, and anecdotal dictionary of proverbs and proverbial expressions (1842); the second, even more impressive (1860), was a series of superlative studies of topics like classification, cultural differences, formal analysis, and the wisdom of nations. ${ }^{3}$ These were not to Paulhan's taste. Instead, living on the occasional romazava (beef and vegetabie stew) and the ubiquitous pink rice 
(vtol), he launched a researcher's career traveling among villages. The letters published by the Société des lecteurs de Jean Paulhan (1982) exhibit his development as a researcher in oral literature. He listened to folk music and watched performers; he overheard a European assault a Malagasy girl; on 15 March 1908, he began recording proverbs $(1982,61-62,97-98,106,112)$.

The genre had long been a favorite subject for foreign investigators, especially the British men sent out by the London Missionary Society.

In the year 1871, [wrote their best folklorist, James Sibree, 1885, 124] the Rev. W. E. Cousins and Mr. J. Parrett published a small volume of 76 pp., containing 1477 Malagasy Proverbs, a branch of native traditional wisdom in which the language is very-rich. A second and much enlarged edition of this work was published in 1885 , containing 3790 proverbs arranged in alphabetical order, so as to be easily found.

The Cousins and Parrett collection (1871), which Paulhan for the time being ignored, was addressed to Europeans, especially the missionaries themselves, as a tool of study; it was not meant to reflect Malagasy for Malagasy readers, most of whom could not read it. Its number of proverbs dwarfs the numbers - four hundred, seven hundredthat Africanist scholars would later rate as substantial collections. Cousins, Parrett, and their cohort faithfully recorded other genres - tales, legends, myths, riddles- but the proverbs held first rank, being seen as relies of an alien belief system which Protestant missionaries were helping towards its death. Proverbs would always be numerous. A century later, a collection by Father Paul de Veyrières (1967) numbered 5633 fitenenana,sayings.

Close at hand was another researcher-educator whose example Paulhan could follow. Charles Renel, rector of the school system and hence Paulhan's superintendent, regularly sent out his staff to collect folktales. Renel's translations $(1910,1930)$ became part of France's movement to aestheticize colonial cultures. When Renel asserted to him that Malagasy was not a proper language, Paulhan rejoined in words later linguists would accept: "Évidemment tout dépend de la définition qu'on donne d'une langue" (1982, 64). Following Renel's example, he started commissioning schoolteachers and other colonials to go into villages, interview old people, and begin gathering manuscripts, as Van Gennep would soon be doing in Algeria (Zumwalt, 1988, 60-64). Over seven months in 1908, he collected seven hundred to eight hundred proverbs which, he said, were not previously known to the missionaries. "Mais il n'y a pas un vazaha[étranger] qui en sache autant que moi," he wrote in a letter of the next year (Paulhan, 1982, 72). Quickly he saw double meanings in them. "J'ai trouvé que la plupart avaient deux sens un tout à fait moral pour les pasteurs européens - et un tout à fait inconvenant, pour eux" $(1982,74)$. He had discovered the most distinctive feature of Malagasy, African, and creole literature: its figurality, that riddling use of language which is found throughout the African continent and the diaspora. "Tout se passe comme s'il n'était pas de mot qui ne puisse être entendu en trois sens différant" (qtd Charles, 1976, 286). Riddling language in Africa, as Geneviève CalameGriaule has shown (1963, 85), simultaneously hides and transmits a speaker's thought; it alludes to delicate, even dangerous matters; it sends messages that the hearer must decipher. So too in Madagascar, the keys to artistic communication are indirection, metaphor, and irony which are tools of the riddle genre. Among African Americans, these aesthetic artifices are known to be sociolinguistic stratagems for interpersonal comment, critique, and "signifying" (Gates, 1988, 77-88; Haring, 1992, 34-62). Having found that 
riddling language in Madagascar, Paulhan was the first to see the Malagasy language in an aesthetic light - to conceive that Malagasy people were doing something more with their words than trying to irritate Europeans by their verbosity. If these people's artistic speaking was so multidimensional, merely to translate it Paulhan would have had to learn to decipher its complex codes and unpack its density. But he wanted to speak it, to become as skilled as a Malagasy man-of-words (mpikabary), analogous to the Caribbean creole "men of words" studied later by Roger D. Abrahams (1983).

Paulhan's involvement with Malagasy verbal indirectness, as shown in proverbs and the genre of oral poetry built out of them, hainteny, has been elegantly and fully demonstrated by Michael Syrotinski (1998, 25-46). Paulhan's first hypothesis about indirectness was that Malagasy proverbs refer continually to eating. He recorded one about an abusive husband: "Quand il rentre de la chasse, il met une cloison au milieu de sa maison. Il met la femme d'un côté et il mange de l'autre." Another mocked the miser: "Quand il mange une anguille salée, il ne songe qu'à ses parents morts", for the miser's living relatives would demand their share (Paulhan, 1982, 62). His second hypothesis, interpreting food as sexual metaphor, would have to wait for later publication (Paulhan, 1987). His collection of over three thousand proverbs (now archived at the Institut Mémoires de l'Édition Contemporaine) was enough of a distraction to cause his supervisor to say he had been neglecting his teaching duties. With no interest in enlisting in colonial administration, Paulhan was sent back to the metropole for doing too much fieldwork in oral literature.

Though it was the obliqueness and ambiguity of proverbs and hainteny that magnetized Paulhan's attention, both in the field and afterwards, he recorded other genres, such as narratives. One was a pathetic histoire malgache, which generically was a dialogic poem between two speakers (Paulhan, 1982, 67-68). One speaker questions a woman more and more closely about her dolorous appearance: "Pourquoi pleurez-vous ?" Repeatedly she conceals her emotional state until at last she confesses, "c'est mon fils qui est mort." The poem ends with a moral in a third voice: "À quoi bon cacher le malheur qui vous a frappé ?" Thirty years before, the British missionary James Sibree had made much of this poem, probably seeing it as a revelation of Merina deviousness $(1889,36)$. Though Paulhan doubtless did collect it in the field, he could have found it also in the 1889 number of the English-language Antananarivo Annual, which Sibree edited.

Early in his stay (1908), he translated another histoire, a Merina trickster story. Several of its episodes were already well known to foreign observers as elements often strung together. The first episode, in which two tricksters meet and join forces for the first time, had been collected and published by Gabriel Ferrand (1893, 201-202). A classic of reciprocal trickery, the story probably appeared also in an earlier, missionarysponsored collection, a forty-two-page collection of trickster tales by Rabezandrina (1875). Throughout that book, the two tricksters Ikotofetsy (Wiley) and Imahaka (Cheatam) gull their neighbours out of food and property. The second episode, also long known in print (Dahle and Sims, 1992, 75-78), is a version of the international type titled "Both?", which bears number 1563 in the Uther-Aarne-Thompson index of folktale plots $(2004,302)$. The two tricksters, having offered to help a noble (andriana) in his field and being sent to his wife to borrow spades, ask her instead for two red shawls (lamba). When she refuses, they call out to the husband, "Elle ne veut pas les donner." He calls back, "Mais voyons Rasoa donne-les vite!" The following episodes abridge a number of incidents from their cycle. In episode 3, the two tricksters live 
peaceably and enjoy villagers' acceptance till the chief accuses them of being thieves and they leave for a year. On their return, unrecognized, they lead an un-trickster life, more acceptable in European eyes: one drinks while the other fishes. In episode 4, one of them, Ikotofetsy, has toothache. He receives no sympathy from his partner, who commences to string his valiha, an absurdly quiet string instrument. When he happens to pluck one string, Ikotofetsy says, "Laisse cela, je suis malade et je ne veux pas entendre de bruit." They part on bad terms, but come back together in episode 5 for a market scene. The twin tricksters set up as vendors, selling the lambas (shawls) they stole earlier, and finally get their comeuppance from a woman who has uncovered their thefts (Paulhan, 1982, 128-134). The three episodes more or less match the conventional trickster style and illustrate the generative power Merina storytellers have always found in stories about deviousness and trickery. Not drawn from earlier publications, they could well have been made up by Paulhan's informant, or someone he learned from. Generating new materials on traditional models has ever been a recognized skill of Malagasy "men-of-words" (Haring, 1992, 15).

In addition to the trickster tales, Paulhan scribbled down a translation of a performed myth (1982, 135-137), in which human beings drive out the hairy aborigines (vazimba), except for one man and one woman, "point courts et criards, mais élancés et graves." At first he distrusts her, for, says the narrator, "lorsqu'on voit beaucoup de femmes, il en est toujours une qu'on méprise un peu," but later they produce children who people the island (motif A1271, "Origin of first parents", in Thompson, 1955-1958, 1, 210). Paulhan knew that the Merina shared such narratives with other Malagasy groups, as Ferrand's 1893 collection had already shown, but for him, the characteristic work of the Merina mind was the haunting, shimmering, poetic hainteny. The avenue to it was the proverb (ohabolana). Working with literate Malagasy in the capital, neglecting his teaching duties, he went through the Cousins and Parrett collection item by item to classify them linguistically (1982, 270 n.1). The work on Malagasy proverbs "was at the source of all of his later theoretical texts on language and literature", says Michael Syrotinski $(1998,26)$. The question how to understand Malagasy indirection and ambiguity pervaded his mind and thinking all his life, becoming the model for his literary theories.

18 Somewhat to his surprise, Paulhan was elected a corresponding member of the Académie malgache. In a communication to them on 28 April 1910, he put forth his idea that proverbs hold a latent place in the Malagasy mind (1982, 203-204). Paulhan's interest in performance, of both proverbs and hainteny, anticipates the emphasis on context that soon became a defining principle in anthropology. Writing of one performer, he wrote that to give meaning to a proverb he was inquiring about, he first had to situate it, surround it, with the very words of the original performance; he could not imagine it outside its surroundings (Paulhan, 1925, 41). Starting from a conventionally Eurocentric assumption that proverbs (ohabolana) were flexible and adaptable, Paulhan moved on to perceiving that they were fixed phrases, sanctified through tradition, closely related to the hainteny he would study next.

Paulhan's attempts to be both observer and participant in Merina artistic communication brought him face to face with the dilemma of his foreignness. Madagascar and France upheld aesthetic principles that were opposed to each other, and the opposition kept undergoing transformations in his thinking. Fieldwork taught him one horn of the dilemma: for Merina mpikabary (men-of-words), authenticity was 
realized by quoting commonplaces and readymade expressions. Their performances of verbal art eschewed the particular and the individual. In their poetics, what had greatest force was what any European would recognize as commonplace and cliché. Merina men-of-words achieved rhetorical persuasion and "authenticity" by using fixed-phrase folklore (Haring, 1992, 63-83, 116-118). Of course in his time in Madagascar, Paulhan himself could never have been anonymous; all colonials were highly visible. But through the years he came to understand the values that Louis Molet $(1959,34)$ discovered later, the value a Merina man put upon staying hidden at home, not risking a snub by his neighbors; the value of keeping his feelings to himself and expressing only what people expect of him. Uneasy except in the heart of the group, it is by shunning individual hair styles, dress, and lamba that one makes his contribution to the uniformity and monotony of the Merina crowd. Ethically, men-of-words depended on precedent; discursively they quoted as much as they could from the tenindrazana, the words of the ancestors.

The other horn of the dilemma came from his own culture. The world of Rimbaud and Verlaine had no tolerance for commonplaces and readymade expressions; wrestling with the irremediable taint of the cliché was Flaubert's life work. From Antananarivo, Paulhan knew the richness, obscurity, and mystery of impersonal poetic language among the Merina; yet Paris was demanding individuality and innovation. For twenty years after leaving the Great Red Island, Paulhan brooded over the proverbs and the hainteny. During World War I, he was posted to the Malagasy soldiers' construction shop at Tarbes, as their interpreter. Doubtless he quizzed them about their traditions. Remembering the mpikabary, he would title his 1941 book les Fleurs de Tarbes and settle the dilemma there.

21 First he had to come to grips with all those proverbs, in the form of two thesis subjects at the Sorbonne. The first, Sémantique du proverbe malgache (as he called it in 1910), took much longer to complete than he expected. He worked at it through the war; made a new start in 1922, by which time he was broadening its subject beyond Madagascar; and remained faithful to it right up to 1939 (Yeschua, 1982, 341). Roger Judrin writes, " cette thèse devait devenir, pour lui, une lourde croix" (in Paulhan, 1982, 253). Only one chapter came to light after the war. Recalling what it was like to be a vazaha (European) fieldworker in Madagascar, he extracted from his thesis-in-progress a deeply reasoned, deeply felt essay about trying to learn to perform Merina verbal art (Paulhan, 1925). It seeks to answer questions like "Comment peut-on parler en proverbes ?" or "Quel est, dans un ensemble de sens donné, la fonction particulière et le rôle du proverbe?" (Paulhan, 1982, 261). The essay has been carefully read only recently, from the literary side by Michael Syrotinski $(1998,30-39)$ and from the folkloristic side by Wolfgang Mieder (1994). It anticipates later linguistic research by Keenan and Ochs (1979). Paulhan frames his experience of foreignness as narrative, being disarmingly candid about his failures as a performer. The more effort he made to speak an ohabolana or hainteny, the less did anything seem to be happening. At last, he says, he lost his initial curiosity; the very terms he used to formulate his anxiety lost their force. He takes his Parisian reader through the difficulties he experienced in the colony, trying to share the doings, concerns, and thoughts of the bourgeois Merina family who were his hosts. At one point, he writes, it began to seem that his speaking of Malagasy lacked weight or conviction; he felt like a university student who knows what he wants to say but lacks an ability to put it across. He knew it was not a character flaw of his own; there must be a second, esoteric language inside ordinary language, momentarily 
piercing through it, always more authoritative (Paulhan, 1925, 27), as there was and is in Madagascar. Here Paulhan discovered what linguists would verify, that there were two registers of Merina speaking, ordinary talk (resaka) and format speaking on ancient models (kabary). Mastery of kabary entitled a speaker to allude, without repeating, to a mass of inherited wisdom, summarized by Paul Ottino:

Supposant la maîtrise de références apprises d'autrui, ce savoir relève d'un univers de connaissances embrassant tout un domaine de traditions mythico-légendaires et historiques structurées sur des généalogies quelquefois appelées tetiarana et sur la trame de récits tantara souvent confondus avec les précédentes qui... sont des sortes de récits d'imitation transposant sur la terre des événements survenus dans un monde imaginal. $(1992,94)$. of language. The dualism became the keystone of Paulhan's literary theory. The second thesis proposal, not shown in the 1925 essay, reverted to a more conventional plan, a linguistic classification of Malagasy proverbial phrases, thus assimilating the native genre ohabolana to a recognizable international genre. It is about the first plan that Roger Judrin concludes, "en fait, elle [la thèse] sous-tend une grande partie de l'œuvre paulhanienne" (Paulhan, 1982, 254). ${ }^{4}$

Paulhan's thesis, published in 1982 by the Société des lecteurs de Jean Paulhan from his last revision, displays indecision: shall it be an essay in classification, or shall it narrate his field experiences? (266-311). He resolves the indecision by classifying proverbs in four categories while insistently keeping them embedded in their communicative context, in contrast to the dry enumerative procedures of Cousins and Parrett. He imitates the style of his Malagasy informants, who could only talk about a proverb by telling a story about it. These little récits are statements about the order of Paulhan's impressions, as the philosopher Stuart Hampshire observes of all classificatory statements (Hampshire, 1959, 26). Indeed the philosopher correctly describes Paulhan's predicament about ambiguity: "many different descriptions might be given of the same [field] experience," (Ibid, 26). Paulhan strongly preferred to write narratives about interactions, in which his statements are as truthful and valid, as explanation, as static descriptions of objects or formal analysis. And his little stories could tolerate obscurity, as the Merina always did. His passion for récit quickly draws him away from the firm logical plan with which he begins, and away from dissertation style. L'œuvre littéraire commence by switching registers of language, following the oral model of Merina speakers citing proverbs in conversation.

More foreign were the hainteny, traditional oral poems, which he translated in his 1913 book. It was clear to Paulhan that like ohabolana, they could be understood only in their performance setting, which was often an argument or dispute. Proverbs and hainteny were imbricated in each other; later formal study made clear their reciprocal relation (Haring, 1992, 98-151). "[L]a clef, pour ainsi dire, d'un hain-teny se trouve dans les proverbes qu'il contient, chaque proverbe... devenant le centre d'une sorte de poème secondaire" (Paulhan, 1982, 203-204). A note on the meanings in hainteny (Paulhan, 1982, 197-209) shows his comprehension of the essence of oral literature as existing in variant forms. There he translates eight versions of the same piece, the first from Dahle's collection $(1877,2)$, and the others collected from old men in Antananarivo. The openings of each version are similar, but the versions differ in their latter half. To interpreting the variant forms as unified, Paulhan finds one central image, a woman whose lover is far away, or lost, or difficult to call back $(1982,203)$. He checked his 
interpretation against a proverb told him by two informants, which expressed a similar idea: “Chant des pintades séparées de l'Andringitra, leur corps est ici, mais leur cœur se répète ce qui se passe là-bas... [La pintade] est le signe placé au front du hain-teny, à quoi on le reconnait" (Paulhan, 1982, 203). The unity of oral and written literature for Paulhan becomes clear when he compares to this hainteny a short story by his contemporary Jules Renard. In both he finds an abstract idea the reader is expected to discern.

Car le proverbe essentiel au récit est souvent caché, à peine évoqué par deux ou trois mots; et l'on dirait qu'il s'agit de ne pas laisser deviner au lecteur l'idée principale du hain-teny, de le dérouter. (Paulhan, 1982, 209).

He acknowledges that his fellow civil servants usually called this behavior dissimulation on the part of the natives.

He made other discoveries that oral literature scholars outside Madagascar would repeat later. ${ }^{5}$ One was the function of the formal register of speaking to end every dispute in the family; this function of social control was later established as a distinctive function of the proverb genre (Abrahams, 1968, 150). Another of Paulhan's discoveries was that special codes, formulas, metaphor, and metonymy were keys to performance, as Richard Bauman would show fifty years later $(1977,15-24)$. His methodological discovery was the attention to performance: the object of field study must be not the words of a proverb, but the communicative context within which it was spoken. The ohabolana had no meaning outside a performance context. Just at this same time, the anthropologist Malinowski was asserting, "the situation in which words are uttered can never be passed over as irrelevant to the linguistic expression" $(1923,306)$. His introspective essay, says Syrotinski, is "an allegory of the very activity of ethnography itself, the complex negotiation of self and other, which is actualized in the drama of the proverbial joust" $(1998,39)$. That was a negotiation not confronted by his contemporaries VanGennep and Saintyves. Paulhan was a forerunner of the interpretive turn of American anthropology in the 1970s and 1980s, in the work of Clifford Geertz, Paul Rabinow, Vincent Crapanzano, and Kevin Dwyer (Trencher, 2000).

When he turned to literary theory, the influence of his fieldwork could be seen, although Paulhan kept Madagascar well in the background. His title, les Fleurs de Tarbes, alludes to his posting among the Malagasy soldiers in wartime; his subtitle, "la terreur dans les lettres", translates the low and high registers of Malagasy speaking into European political terms, by evoking the oppressive measures adopted between the fall of the Girondins in June 1793 and Robespierre's fall on 27 July 1794. What Paulhan calls terror in (European) literature is the most forceful factor in the kabary he had observed in Madagascar: the special power commonplaces and readymade expressions have over speakers and audiences. Literary terrorism bullies us into avoiding clichés: "L'esprit se trouve, à chaque moment, opprimé par le langage" (Paulhan, 1941, 65). But in Madagascar, the esprit was not so oppressed: the readymade expressions had been hallowed and bequeathed by the ancestors. Perhaps Paulhan had never given up the old dream of a language that would exactly express our thought, as Michel Beaujour has said $(1976,128)$. Mere representation anyway did not interest him; he was drawn to the secret and the unsaid from his experience with the hainteny. "Le poème ou le roman expriment sans doute la joie, le désespoir, les hommes et leurs mœurs, mais trahissent plus secrètement une idée du langage." (Paulhan, 1941, 74). The secrecy and allusiveness in the Malagasy conception of language, as he discerned it from those old men in 
villages, as he saw it in the texts he and his predecessors collected, and as he guessed at it through his attempts to perform hainteny, still captivated him.

Viewing literature from the perspective of the Indian Ocean, Paulhan manages to treat the prevalent French literary ideology, says Michel Beaujour, as a mere local, ephemeral phenomenon $(1976,129)$. So, though he mentions Sigmund Freud, he does not see the relevance of slips of the tongue, where reality breaks into being expressed through a person's habitual controls. Though he mentions the Sorbonne linguist Antoine Meillet, he takes no account of Ferdinand de Saussure, whose severance of words from their meanings (now a commonplace in its own realm) would have been useful to him. Instead his model is the skill of the Malagasy mpikabary in positioning old words in a new setting. There is such a thing as a surprising proverb, he declares; there is such a thing as an ingenious cliché (Paulhan, 1941, 147). Ambiguity rules.

Against the literary convention that writers must avoid cliché and seek their own authentic thought stands the ineluctable power of the cliché, which in Madagascar was sanctioned by the ancestors. Certain oft-repeated words, he said, betray hypertrophy, overgrowth, excessive development, at the expense of the idea, of substance, indeed of language itself. Well before George Orwell, Paulhan pointed to the extra-semantic power of words like democracy and infinite, which he said are understood incompletely or not at all. Either they act directly on one's mind, inhibiting clear thinking, or they are employed coldbloodedly for their effect. We too rely upon clichés and pre-existing, useless fixed phrases; we internalize certain commonplaces. Remembering what he observed among the Merina, Paulhan sees that:

Bien au contraire voit-on, partout où certains proverbes ou dictons sont de mise comme il arrive chez les paysans, à l'intérieur d'un parti politique ou d'une même famille - les interlocuteurs s'entendre sur le courant d'une expression, et constamment user de clichés sans jamais buter à leur langage. $(1941,142)$.

Even the folk sayings of the bourgeois, which the unacknowledged ethnographer Flaubert assembles in the Dictionnaire des idées reçues, can be so internalized that they feel to us like things we invented (Paulhan, 1941, 92-93).

Had Paulhan been terrified by the sociolinguistic strangeness of the Merina? Terror arises, he says in 1941, when a receiver no longer shares the rhetorical assumptions of a sender -when the rhetoric is experienced as alien (Beaujour, 1976, 130)- as he experienced the Merina hainteny. His friends Cocteau, Breton, and Aragon were alienating readers through using commonplaces deliberately, as part of their estranging technique. Madagascar supplied him with materials for ethnographic surrealism, the aesthetic "that values fragments, curious collections, unexpected juxtapositions" from exotic sources (Clifford, 1988, 118; Beaujour, 1976, 141). Les Fleurs, indeed, is a kind of dialogue with the surrealists around him, as it is a dialogue with the memories of his Merina family. Paulhan's spotlight on rhetoric had little effect in Paris, critics now say (Bersani, 1976, 143), and no one noticed he had imported it from the colony.

The days of fieldwork in Antananarivo break into les Fleurs de Tarbes when Paulhan cites a proverb from the Bara of southern Madagascar: "L'homme est un couteau mouillé : si tu ne frotte pas chaque jour la lame et l'étui, il rouille bientôt" $(1941,157)$. It echoes a Merina proverb, Antsibe latsaka an-dobo; raha ilaozana, haratesina, a big knife dropped in a pond; if it's left [there], it will rust (Houlder, 1957, 11, no. 127). But he was not plagiarizing Malagasy kabary: he was theorizing and importing its rhetoric. Not the 
rhetoric of speaking well: it is a rhetoric which "préfère écouter ce que dit le Malgache ou, chez nous, l'homme de la rue" (Belaval, 1976, 254). That would mean fieldwork: in Madagascar, listening for ohabolanaand hainteny; in Paris, listening for the commonplaces of vernacular discourse. In literature, says Paulhan, for all we know, some literary commonplaces may have cost the writer long effort $(1941,92)$. Towards the end of his book, he proposes a literary program: "The cliché... has to be ceaselessly considered, put in question, cleaned up" (1941, 172). Was he addressing himself to readers, critics, or writers (Bersani, 1976, 143)? Seeing French literature from the incongruous perspective of Madagascar yields a modernist archaism analogous to Picasso's absorption of African art. In another attempt to understand the colonized Malagasy, Paulhan's comparison of Merina attitudes towards eating and European attitudes toward sex was incongruous enough for him to withhold it from publication (Paulhan, 1987).

In the next generation, from another Southwest Indian Ocean island, the Mauritian surrealist poet and painter Malcolm de Chazal took up Paulhan's inquiry into the power and force of language (Joubert, Osman and Ramarasoa, 1993, 137-149). Reading Chazal sent Paulhan back to contrasting him with the Malagasy mpikabary. Paulhan respected Chazal enough to identify his science of correspondences with analogous revelations in the Kabbalah, theosophy, and occultism. If a Mauritian like Chazal acknowledged no traditions but the ones he fabricated, could the source of his authority be no more than the virtue of the image? Can poetic authority reside only in the image thrown up by the poet, who becomes the bridge between meanings, between the rules of nature, between the rungs on the world's ladder? After all, the case for hainteny as poetry rests on comparatism: its use of consonance and assonance, repeated words, parallelisms, and symmetries. Could a surrealist from Mauritius illuminate a comparative study of poetics?

Situating les Fleurs de Tarbes in literary history, Michael Syrotinski characterizes it as

a performance of the very radical ambiguity that it talks about, an ambiguity that is not simply an equivocation about what the book is saying, but that suspends it between saying and doing, stating and performing, original and commonplace. $(1998,92)$.

Consequently the solution Paulhan proposes to the tension is a necessary failure through being a parody of understanding.

The ultimate negation in les Fleurs de Tarbes still shows the weight of those years among the Merina. The last sentence of the book reaffirms secrecy: "Mettons enfin que je n'ai rien dit" (Paulhan, 1941, 177). His book turns back on itself to leave the reader puzzled. The sentence echoes the Merina expression "killing [your] words at home" (=mono volana an-drano), which seems to mean not revealing what you think, but just acting (unwisely) on your own, without consulting anyone (Houlder, 1957, 148). The secrecy this line proclaims has enduring significance for Paulhan. Citing another last sentence, from the novel le Guerrier appliqué, Silvio Yeschua declares:

Pour ma part, le remarquable, c'est que le dernier mot du livre soit le mot "secret», plus pertinent, me semble-t-il, quand on parle de Paulhan, que la dichotomie culture-nature. Ou bien alors, si l'on tient à cette espèce de découpage, il faut mettre dans la culture ce que tout à l'heure j'appelais les langages, tandis que la nature relèverait $\mathrm{du}$ secret, de cet indicible autour duquel on ne peut que tourner. (in Bersani, 1976, 38). 
Paulhan never forgot how skillful the Malagasy had been at guarding their secrets, in both language and silence. If a colonized people would always keep their secrets from the colonizer, the colonial ethnographer yet would never cease circling around them. Did the colonizers not also imitate them? After the Liberation, Sartre could reveal in 1944 the secret republic, the république du silence, which had been founded during the war.

Rather in the spirit of Paulhan's self-consuming final sentence, Maurice Blanchot, reviewing les Fleurs de Tarbes in the Journal des Débats (1941), at first gave it high rank, then later withdrew the accolade (Syrotinski, 1998, 80). Having no interest in vernacular expression, Blanchot was strongly influenced by Paulhan's perennial malgachitude. Concealing or ignoring whatever debt or imitation he might owe to Paulhan's mpikabary, Maurice Blanchot said nothing of the fertilization of French criticism that had come from the colony. He reshaped and transformed Paulhan's Malagasy-based aesthetic into his conception that (in Steven Ungar's words, 1993, 254), literature had a unique capacity "to negate the world in order to recreate it as language". The Merina had long ago mastered the art of creating through language a social world always honoring ancestral custom, leaving room always for ordinary talk and conversation. The force of their small-group communication, which Paulhan had learned in Madagascar, was abandoned in Blanchot's transformation, but the hidden ancestor of Blanchot's impersonality was the discourse of the Merina. Paulhan discovered it in the poetic language of the Merina.

[P]arlant en général d'un proverbe l'on ait en vue toute autre chose qu'une phrase donnée, formée de certains mots, propre à rendre certains faits ; [il est] exactement le contraire d'une phrase : un événement indépendant de tous mots, un fait qu'il s'agit d'exprimer. $(1925,37)$.

They would surely have agreed with Blanchot on the power of language to affect the world, which Paulhan directly experienced. Houlder's classic collection (1960) demonstrates that the Malagasy had a clear conception of good and bad ways of speaking.

Monge-mahefa (proverbial phrase), qui parle peu, mais dont les paroles ont beaucoup d'effet (31).

Teny zato, kabary arivo; fa iray many no marina, Cent paroles, mille discours; un seul est vrai (36).

Aza atao Caria azon' adala, Ne faites pas comme un imbécile ayant entendu une conversation (140).

Ao am-bava no aretina, Ce sont les paroles (mauvaises ou injustes) que vous dites qui sont une maladie (173).

But such classification did not appeal to Paulhan. Never one to ignore the dependence of proverbs on metaphor, by practicing performance he imitated the Merina capacity for pervading life with metaphor, and anticipated the efforts of contemporary proverb scholars, for example Cécile Leguy (2008), to replace meanings in their native setting. The force of Merina poetic language, as bequeathed by the ancestors, existed outside its expression; its force was beyond verbal. Paulhan's distinction, which permeates les Fleurs de Tarbes, is quite visible, though unacknowledged, in Blanchot's 1949 essay on Mallarmé.

The Merina would also have agreed with Maurice Blanchot on the impersonality of poetic language. They assign authorship of their oral literature (fitenin-drazana) to ancestors, who however are more or less accessible; the parallel for Blanchot is that the 
what or who that writes is a depersonalization in ourselves (Meschonnic, 1973, 103). Many Malagasy folktales end in impersonality, with a disclaimer of personal responsibility by the storyteller. Avoidance of personal responsibility, or culpability, weighs upon any Malagasy whether acting, speaking, or thinking, says Richard Andriamanjato $(1957,16)$. Public speech (kabary) invariably disclaims any innovation in ancestral custom, for innovation would invite tsiny, reproach. The Merina might even have agreed with Blanchot that the word has a capacity of evoking absent things (for them, ancestors) and asserting their absence and presence at the same time (1955). But he never acknowledged, indeed may never have seen, the parallels between their formal language (kabary) and his écriture hors langage.

Yet Blanchot's connection to Paulhan and their common commitment to allusiveness was already visible to Georges Perec in 1962, who saw the relevance of les Fleurs de Tarbes to both Blanchot and the nouveau roman of Alain RobbeGrillet. For the nouveau roman, an essential requirement was that one had to read between the lines, and that tendency had already been "consecrated" by Paulhan and Blanchot (Perec, 1962). From Mallarmé, as is well known, Blanchot developed his concept of the generality and impersonality of poetic language. He was fond of quoting this sentence of Mallarmé's, from 'L'action restreinte':

Impersonnifié, le volume, autant qu'on s'en sépare comme auteur, ne réclame approche de lecteur. Tel, sache, entre les accessoires humains, il a lieu tout seul: fait, étant. (Paul de Man, 1983, 68).

Unwittingly he was also developing that concept from Paulhan's Madagascar experience. Later, Paul de Man in his turn made much of Blanchot's claim for poetic impersonality (Paul de Man, 1983), though he cared nothing for its pre-Mallarmé history. Following his guiding principle of negativity, Blanchot says nothing of Malagasy sources, which Paulhan neither concealed nor proclaimed. The Merina had discovered an answer to Blanchot's question, "How is literature possible?" It is possible because fixed phrases, in kabary, have a power of their own; because oft-quoted proverbs can surprise us, in a new social situation; because we can find even clichés ingenious. These insights came to Paulhan from Merina discourse; Blanchot quietly welcomed them. Underlying the claim to disinterested impartiality was an unacknowledged colonialist stance. Forces in the context of French culture enabled Maurice Blanchot to keep secret whatever debt he may have owed to Malagasy men-ofwords.

Blanchot's critics and enthusiasts, accepting his notion of impersonality, also accept his exclusion of oral literature. Perhaps the end of the twentieth century was the last generation in which a critic as eminent and astute as Paul de Man could be so ignorant of oral literature or ethnography. When de Man read Paulhan, he saw no reason to penetrate to the Merina interpretative codes and conventions, which were as much a metaphor for self-reading as Blanchot's impersonality. For de Man, Blanchot is as much a blinded critic as György Lukàcs, Georges Poulet, or Jacques Derrida. Blanchot's criticism thus becomes for de Man "a form of demystification on the ontological level that confirms the existence of a fundamental distance at the heart of all human experience" (Paul de Man, 1983, 76). Yet the visible parallel between Malagasy folk literature and Blanchot's conception of poetic language is a link through Paulhan, and afterwards to deconstructive criticism - which of course had its own secrets. 
Long after World War Two, Paulhan's name turned up in another context of secrecy. Obituary notices in 1998 revealed the secret of his long-term secretary, Anne Desclos, who generally disguised herself with the name Dominique Aury. Under the nom de plume of Pauline Réage, she wrote in 1954 the best-selling erotic novel Histoire d'O, with a preface by Paulhan. The obituaries uncovered the pseudonym and implied the couple's secret: this novel of sexual subservience was dedicated to him as a tribute to her master. Was the subservience only metaphorical? Biographical answers differ, but everyone agrees, not only in France, how useful secrecy is when one is engaged in adultery. If his Madagascar research was no secret to Breton, Éluard, or Sartre, yet his literary character concealed his identity as a researcher of oral literature.

Outside France, the magnitude of Paulhan's influence has lain rather in the shade; within France, writers far more acclaimed -Roland Barthes, Gérard Genette- have been called Paulhan's knowing or unknowing disciples, by Jean-Yves Tadié (1987, 203, 246). Oral literature was not much affected by the convergence of disciplines represented by names like Barthes, Greimas, Todorov, Foucault, Canetti, and Benveniste. Closer to their discoveries was Georges Dumézil's work on myth, which however depended on written texts (some very ancient). Closest was the ethnolinguistique created by Geneviève Calame-Griaule. Had the ethnographic world taken notice of Paulhan's sense of the continuum between the oral and the written; had the literary world regarded Malagasy ohabolana and hainteny as models for poetry; had literary criticism or sociolinguistics seen that the Merina of Madagascar devised ways of saying the unsaid through the said, and were therefore a model for Europe; then a bridge might have been commenced between oral and written literary studies. But the two disciplines staked out their territory, each claiming narrative and poetry as its own. The most coveted object was myth. History, literature, anthropology, and comparative religion all proclaimed definitions of myth, despite Dumézil's repeated attempts to discourage generalization by asserting, "There are only particular cases." Each discipline claimed the right to ignore the definitions of others. One university professor in the United States has postulated that the study of myth should be autonomous, because myth itself is autonomous. Unfortunately the contrary of that proposition is true: myth is whatever a particular textual community says it is (Haring, 2001). Paulhan's translations of hainteny illustrated the Merina genre, implying that every textual community has an indefeasible right to its own nomenclature. Only in the period of structuralism, long after the conversation between les Fleurs de Tarbes and l'Espace littéraire, did another conversation begin about socially employed systems of communication. Paulhan, in his refined, high-pitched, almost feminine voice, might well have had a contribution to make to that conversation, recalling his field experience. His defense of the poetic character of Malagasy oral literature, against the European expectation that the colonized must be too primitive to know real poetry, was timely, but not timely enough to create a visible link between oral literature studies and the official literary world. 


\section{BIBLIOGRAPHY}

ABINAL, R. P., MALZAC, Victorin, 1963, Dictionnaire malgache-français, Paris, Éditions Maritimes et d'Outre-Mer [1 1 ère éd., 1888].

ABRAHAMS, Roger D., 1968, Introductory Remarks to a Rhetorical Theory of Folklore, Journal of

American Folklore 81, pp. 143-158.

ABRAHAMS, Roger D., 1983, The Man-of-Words in the West Indies, Baltimore, Johns Hopkins University Press.

ANDRIAMANJATO, Richard, 1957, le Tsiny et le Tody dans la pensée malgache, Paris, Présence africaine.

BAUMAN, Richard, 1977, Verbal Art as Performance, Prospect Heights (IL), Waveland Press.

BEAUJOUR, Michel, 1976, Jean Paulhan et la terreur, in Jacques Bersani (dir.), Jean Paulhan le souterrain, Paris, Union Générale d'Éditions, coll. « 10/18 », p. 118-150.

BEAUVOIR, Simone de, 1960, la Force de l'âge, Paris, Gallimard.

BELAVAL, Yvon, 1976, l'Idée de rhétorique chez Jean Paulhan, in Jacques Bersani (dir.), Jean Paulhan le Souterrain, Paris, Union Générale d'Éditions, coll. « 10/18 », p. 250-267.

BELMONT, Nicole, 1974, Arnold Van Gennep, créateur de l'ethnographie française, Paris, Payot.

BENDIX, Regina, 2000, Folklore between the Disciplines, Then and Now, paper presented at National Endowment for the Humanities, Washington (DC).

BERSANI, Jacques (éd.), 1976, Jean Paulhan le souterrain, Paris, Union Générale d'Éditions, coll. «10/18».

BLANCHOT, Maurice, 1942, Comment la littérature est-elle possible ?, Paris, José Corti.

CALAME-GRIAULE, Geneviève, 1963, l'Art de la parole dans la culture africaine, Présence africaine, $\mathrm{n}^{\circ}$ 47, p. 73-91.

CHARLES, Michel, 1976, Conscience et inconscience du langage : Jean Paulhan et la notion de figure, in Jacques Bersani (dir.), Jean Paulhan le souterrain, Paris, Union Générale d'Éditions, coll.

«10/18 », p. 280-315.

CLIFFORD, James, 1988, The Predicament of Culture: Twentieth-Century Ethnography, Literature, and Art, Cambridge (MA), Harvard University Press.

COUSINS, W. E., and PARRETT, John (eds), 1871, Malagasy Proverbs, Antananarivo.

DAHLE, Lars, 1877, Specimens of Malagasy Folk-Lore, Antananarivo, A. Kingdon.

DAHLE, Lars, Sims, John (eds), 1992, Conte des aïeux malgaches (anganon'ny ntaolo), Paris, INALCO, coll. « Études océan Indien » [trad. Denise Dorian et Louis Molet].

EVANS-PRITCHARD, E. E., 1960, Introduction in Robert Hertz, Death and the Right Hand, London, Cohen and West [transl. Rodney and Claudia Needham].

FERRAND, Gabriel (éd.), 1893, Contes populaires malgaches, [recueillis, traduits et annotés par], Paris, Ernest Leroux, « Collection de Contes et de Chansons Populaires, XIX ».

Fox, Leonard, 1990, Hainteny, the Traditional Poetry of Madagascar, Lewisburg (PA), Bucknell University Press. 
GATES, Henry Louis, 1988, The Signeing Monkey: A Theory of Afro-American Literary Criticism, New York, Oxford University Press.

GRIAULE, Marcel, 1948, Dieu d'eau : entretiens avec Ogotemmêli, Paris, Éditions du Chêne. HAMPSHIRE, Stuart, 1959, Thought and Action, London, Chatto and Windus.

HARING, Lee, 1992, Verbal Arts in Madagascar: Performance in Historical Perspective, Philadelphia, University of Pennsylvania Press.

HARING, Lee, 2001, Textual Communities for Oral Literature, Cahiers de littérature orale, 50, pp. 185-205.

HOULDER, John Allen, 1957, Ohabolana, ou proverbes malgaches, Tananarive, Imprimerie Luthérienne [trans. H. Noyer].

HYMES, Dell, 1964, Introduction: Toward Ethnographies of Communication, American Anthropologist 66, pp. 1-34.

JAKOBSON, Roman and BOGATYREV, Petr, 1971, On the Boundary between Studies of Folklore and Literature, in Ladislav Matejka and Krystyna Pomorska (eds), Readings in Russian Poetics, Cambridge (MA), The MIT Press.

JOUBERT, Jean-Louis, OSMAN, Amina, RAMARASOA, Liliane, 1993, Littératures francophones de l'océan Indien, île Maurice, Éditions de l'océan Indien.

KEENAN, Edward Louis, and ocHS, Elinor, 1979, Becoming a Competent Speaker of Malagasy, in Timothy Shopen (ed.), Languages and Their Speakers, Cambridge, Winthrop, pp. 113-158.

LEGUY, Cécile, 2008, En quête de proverbes, Cahiers de littérature orale, 63-64, p. 59-81.

MALINOWSKi, Bronislaw, 1923, The Problem of Meaning in Primitive Languages, in C. K. Ogden and I. A. Richards, The Meaning of Meaning, London, Routledge and Kegan Paul, pp. 296-336.

MAN, Paul de, 1983, Impersonality in the Criticism of Maurice Blanchot, in Paul de Man, Blindness and Insight: Essays in the Rhetoric of Contemporary Criticism, Minneapolis, University of Minnesota Press, pp. 60-78.

MESCHONNIC, Henri, 1973, Poésie sans réponse, Paris, Gallimard.

MIEDER, Wolfgang, 1994, African Proverb Scholarship: An Annotated Bibliography, Colorado Springs, African Proverbs Project.

MOLET, Louis, 1959, Esquisse de la mentalité malgache, Revue de psychologie des Peuples $14, \mathrm{n}^{\circ} 1$, p. $25-40$.

оттіNo, Paul, 1992, les Discours oratoires kabary et les 'joutes de paroles' hain-teny, in le Scribe et la Grande Maison. Études offertes au professeur J. Dez, Paris, INALCO, coll. «Études océan Indien »15, pp. 93-104.

PAULHAN, Jean, 1925, l'Expérience du proverbe, Commerce 5, p. 23-77.

PAULHAN, Jean, 1941, les Fleurs de Tarbes ou la Terreur dans les lettres, Paris, Gallimard.

PAUlHAN, Jean, 1982, Jean Paulhan et Madagascar, 1908-1910, Paris, Gallimard, “ Cahiers Jean

Paulhan ", $\mathrm{n}^{\circ} 2$.

PAUlHAN, Jean, 1987, le Repas et l'Amour chez les Mérinas, Paris, Fata Morgana [1ér. é., 1970].

PÉREC, Georges, 1962, Pour une littérature réaliste, Partisans, 4. 
QUITARD, Pierre Marie, 1842, Dictionnaire étymologique, historique, et anecdotique des proverbes et des locutions proverbiales de la langue française, Paris, P. Bertrand.

QUITARD, Pierre Marie, 1860, Études historiques, littéraires et morales sur les proverbes français et le langage proverbial contenant l'explication et l'origine d'un grand nombre de proverbes remarquables oubliés dans tous les recueils, Paris, Téchener.

RABEZANDRINA, 1875, Ikotofetsy sy Imahaka, sy iantara malagasy hafa koa, Antananarivo, John Parrett. RENEL, Charles, 1910-1930 Contes de Madagascar, Paris, Ernest Leroux. « Collection de Contes et Chansons Populaires ", t. XXXVII-XXXVIII, XLVI.

RICHARDSON, John, 1885, A New Malagasy-English Dictionary, Antananarivo, The London Missionary Society.

SCHLEGEL, Friedrich von, 1865, Lectures on the History of Literature, Ancient and Modern, London, Ball \& Daldy.

SIBREE, James, Jr., 1885, Literary notes, Antananarivo Annual and Madagascar Magazine 9, pp. 122-127.

SIBREE, James, Jr., 1889, The Oratory, Songs, Legends and Folk-Tales of the Malagasy, Antananarivo Annual 13, pp. 28-38.

SYROTINSKI, Michael, 1998, Defying Gravity: Jean Paulhan's Interventions in Twentieth-Century French Intellectual History, Albany, State University of New York Press.

TADIÉ, Jean-Yves, 1987, la Critique littéraire auxxe siècle, Paris, Belfond.

THOMPSON, Stith, 1955-1958, Motif-Index of Folk-Literature: a Classification of Narrative Elements in Folktales, Ballads, Myths, Fables, Mediaeval Romances, Exempla, Fabliaux, Jest-Books, and Local Legends, Bloomington, Indiana University Press.

TRENCHER, Susan R., 2000, Mirrored Images: American Anthropology and American Culture, Westport (CN), Bergin \& Garvey.

TRUDEL, Eric, 2004, Those Who Have Fallen Silent's: Keeping Literature 'Au Secret', Yale French Studies 106, pp. 173-188.

UNGAR, Steven, 1985, Paulhan before Blanchot: from Terror to Letters between the Wars. Studies in Twentieth Century Literature 10, 1, pp. 69-80.

UNGAR, Steven, 1993, Blanchot, Maurice, in Irene Rima Makaryk (ed.), Encyclopedia of Contemporary Literary Theory: Approaches, Scholars, Terms, Toronto, University of Toronto Press, p. 253-255.

UTHER, Hans-Jörg, 2004, The Types of International Folktales: A Classification and Bibliography, Helsinki, SuomolainenTiedeakatemia.

VAN GENNEP, Arnold, 1904, Tabou et totémisme à Madagascar : étude descriptive et théorique, Paris, Ernest Leroux.

VEYRIÈRES, Paul de, 1967, le Livre de la sagesse malgache, Paris, Éditions Maritimes et d'Outre-mer. YESCHUA, Silvio, 1982, Jean Paulhan et les hain-teny: de l'étude savante au récit initiatique, in Jean Paulhan, Jean Paulhan et Madagascar, 1908-1910, Paris, Gallimard, « Cahiers Jean Paulhan », $\mathrm{n}^{\circ} 2$. zUMWALT, Rosemary Lévy, 1988, The Enigma of Arnold Van Gennep (1873-1957): Master of French Folklore and Hermit of Bourg-la-Reine, Helsinki, Suomolainen Tiedeakatemia. 


\section{NOTES}

1. Michel Léon characterizes Paulhan as "ce personnage qui dépouillait si bien les mots sans jamais se découvrir" (Paulhan, 1982, 165).

2. Information about Paulhan's life and career comes from Société des lecteurs de Jean Paulhan. Frequent references to 'Paulhan 1982' point to the collection Jean Paulhan et Madagascar published by the Société des lecteurs de Jean Paulhan. I am grateful to Dorothy Noyes for her advice in writing this paper.

3. I owe these references to Professor Wolfgang Mieder, the world authority on the proverb, to whom I and all folklorists are ever indebted.

4. Sometimes in his editing work, Paulhan would show his approval of something in a text by writing $t s$, an abbreviation for the Malagasy tsara, good. How many readers could translate that secret? It was revealed after his death by his secretary, Anne Desclos/Dominique Aury/ Pauline Réage (Bersani, 1976, 109).

5. Long after Paulhan's death, it was an American, Leonard Fox, who made the most comprehensive collection and translation of Malagasy hainteny (Fox, 1990).

\section{ABSTRACTS}

Important and influential as Jean Paulhan (1884-1968) was in the literary world of Europe l'entredeux-guerres, his studies of oral literature in Madagascar, which he carried out before World War I, underlay his prodigious achievements as editor and theoretician. His creation of a place for Madagascar in the European mind did not bring about a larger place for oral literature in the literary establishment, despite his bridging the gap between the two.

Bien que doyen du monde littéraire français dans l'entre-deux-guerres, Jean Paulhan (1884-1968) a entrepris de grandes recherches dans la littérature orale malgache qui ont profondément influencé sa pensée théorique. Médiateur de deux mondes littéraires, il n'a pas, malgré ses efforts, réussi à combler le fossé entre la littérature orale et la littérature établie.

\section{INDEX}

Geographical index: Madagascar

Keywords: Malagasy, Paulhan Jean (1884-1968), Orality, Proverb

Mots-clés: Paulhan Jean (1884-1968), oralité, proverbe

Subjects: littérature orale

\section{AUTHOR}

\section{LEE HARING}

Brooklyn College 